quaspes of an abnormal state of the liquor sangrinis, may be countaracted by the appropriate remedy.

Finally, none of the liquids mentioned in these experiments produce any troubling or deposit from the liquor sanguinis. A molecular matter, or a red colour appearing, is a proof of the destruction of many corpuscles; and the place where the destruotion has occurred may always be found, unless there be streams flowing fast in the liquid. And it is very necessary, in repeating my experiments, to allow for the effect of these streams. In using the high powers of the microscope, rapidity of manipulation is impossible: the addition of the smallest quantity of an extraneous fluid to a drop of blood destroys some corpuscles, and alters the form of others, so that by the time the object can be placed in the focus of the object. glass, streams of fresh corpuscles may be Howing over the place of the destroyed ones; hence, the extremes between destruction and no alteration in the corpuscles mas, perchance, be brought together. The observer must follow out the course of the streams, which frequently give important assistance in the observations.

Norfolk Square, Brighton, November $18 \%$.

\section{OBSERVATIONS ON THE MORBID ANATOMY, PATHOLOGY, AND DETERMINING CAUSE OF EMPHYSEMA OF}

\section{THE LUNGS.}

By A. T. H. WATERS, M.R.C.P., Physician to the Liverpool Northern Hospital; Lecturer on Anatomy, Physiology, and Pathology, in the Liverpool Royal Infirmary School of Medicine.

[Read before the Royal Medical and Chirturgical Society.]

\section{Part I.}

Views of Pathologists before the time of Lacnnec, and of the latter author. Frequency of the Disease. Importance of a knovledge of the Minute Structure of the Lung. Ultimate Pulmonary Tissue; its Arrangement and Structure. The different kinds of Enphysema. Vesicular Emphysema; its various forms. Mfodes of Preparation of Lung Tissue for examination. Changes which take place in the Air. Sacs in the different Stages of the Disease. Condition of the Blood-Vessels; of the Bronchial Tubes. Is the Disease attended with any Degeneration of Tissue? Interlobular Empluyserna.

Previously to the time of Laennec, pulmonary emphysema was considered by pathologists as produced by an infiltration of air into the areolar tissue of the lungs. An imperfect knowledge of the anatomy of these organs, led to the supposition that a rupture of the air-cells would give rise to extravasation of air into the tissue, by which they were connected with each other. An improved anatomical knowledge and further pathological inquiry, have shewn us that the quantity of areolar tissue in the lungs is very small, that extensive rupture of the air-cells may take place without infiltration of that tissue re. sulting, and that the only parts where such infiltration does occur are those in which the above-named tissue surrounds the various lobules.

Laennec was the first to drav the distinction between the two kinds of pulmonary emphysema; viz., vesicular and interlobular. The former lie recognised as consisting in a dilata. tion or distension of the ultimate portions of the air.tubes. Subsequent researches have tended to prove the correctness of the French physician's observations in this respect, although the theory he advanced of the determining cause of the disease, as I shall have hereafter to show, has given way under an im. proved knowledge of the physiology of respiration, and more extended patholozical inquiry.

Since the time when Laennec wrote, many able observers have directed their attention to this disease; nevertheless, the information we possess with reference to it is insufficient to enable us to generalise with certainty on its essential nature and there are numerous points in connection with its patho. logy and determining cause on which investigations are neces. sary, in consequence of the diversity of opinion which exists thereon.

Of the great frequency of the affection in varying degrees of severity, no one who has been engaged in extensive public or private practice, can entertain any doubt; and, considering the gravity of the symptoms the disease produces in its progress, and the tendency which exists for other organs to become secondarily involved, wo cannot but edmit the great importance of an early recognition of its symptoms, and a more accurnte bnowledge of its essential natrure.

In speaking of the disease, Lebert hes the following remark in his Pathological Anatomy. "Fow disenses have given rise in the last twenty years to so many theories, 80 many explanetions, more or less conjectural, and as no one of them appears to us satisfactory in the present state of science, it is the more essential to describe in a rigorously exact manner everything which relates to this affection, in order that for the future these materials may serve to establish doctrines more generally satisfactory on the subject."

Again, writing on the same subject, Rokitansky observes :"The conditions giving rise to the production of emphysema, and its pathology in general, although much labour has been devoted to the affection, are still far from clear.

To the study of morbid anatomy and pathology, a knowledge of minute structure is essential; hence the rapid strides which these sciences have made since the microscope has revealed to us the intimate arrangement of the various organs of the body but, important as such knowledge is to the full appreciation of all diseased structure and function, its value becomes doubly manifest with reference to the disease now being considered, for there is probably no affection of the body, the symptoms and physical signs of which are so readily explicable from an acquaintance with the structural changes and modifications from the conditions of heulth by which it is accompanied, as that of pulmonary emphysema.

Strongly impressed with the force of Lebert's remark, that it is " essential to describe in a rigorously exact manner everything which relates to the affection," and therefore to detail minutely the progressive changes which take place from the earliest periods of the diseuse to the time of its full develop. ment, it becomes necessary for me briefly to describe the intimate structure and arrangement of the ultimate pulmonary tissue, in order that the changes above alludecl to, of which it is the seat, may be the more readily understood.

The bronchial.tubes of the lungs, after several divisions and sub-divisions, which for the most part are of a dichotonous nature, terminate in a dilatation, into which open a number of cavities, which constitute the ultimate expressions of the airtubes. These cavities, to which various names have been given, I have elsewhere called air-sacs, as being, in my opinion, more appropriate to their shape and urrangement than any term hitberto used; and the series of air-sacs connected with the extremity of each bronchial twig, with its system of bloodvessels, etc., I have called a lobulette.

Every lobule of a lung is composed of a number of lobulettes, and thus the description of a single lobulette will suffice for that of the entire lobule.

Each lobulette consists of a collection of air-sacs, which vary in number from six to twelve. 'The air-sacs are somewhat elongated cavities, communicating with the dilated extremity

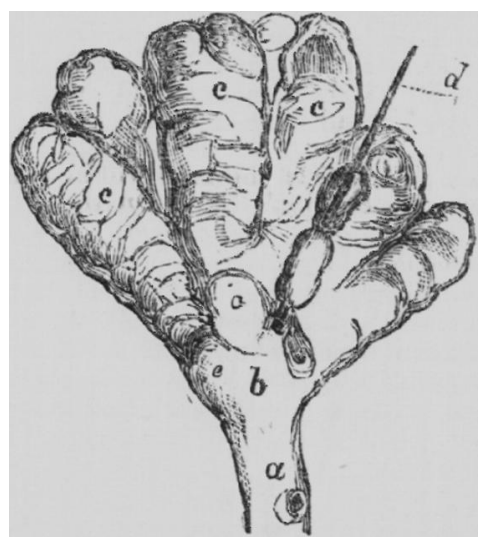

Fig. 1.-Healthy IIuman Lung. Irawing of a terminal bronchial tube, with a group of air-sncs, or lobulette, connected with it. $a$, the with a gloup of air-sics, or lohulette, connected with it. $a$, the bronchial tube; $c$ individus air-sacs. At $d$, bristle is seen passed into an air-sac; one end is seen opening into the common passed into an air-sac; one end seen opening into the common carity in which the bronchia tube terminates. At $c c$, are seen the openings of other sacs which lie bencath those which are ex-
posed; six sacs are seen converging to the common centre. The posed; six sacs are seen converging to the common centre.
markings in the air-sacs denote the boundaries of the alveoli.

of a bronchial tube by a circular opening, which is usually smaller than the sac itself, and has sometimes the appearano 3 of a circular hole in a diaphragm. When this is the case, the 
sac dilates suddealy beyond the opening. The seco of the lobulotto are placod side by side, and are separated from each other by thin membranous walls. Their shape, when properiy inflated, or when distended by some material which has set in them, as gelatine, or a mixture of wax and turpentine, is polygonal. They approach the circular form, but in consequence of their mutual pressure, the parietes become somewhat flattoned. The sacs increase slightly in size as they pass from the bronchial tube to their fundus, the latter being usually the broadest part of the sacs; but they often have an almost uniform diameter throughout. All the sacs pass from the ex. tremity of the bronchial tube tovards the circumforence of the lobule of which the lobulette forms a part; they consequently radiate from the tip of the bronchial twig. The sacs connected with one lobulette do not communicate with those of another lobulette. As the sacs pass towaris the boundary of the lobulette, they often bifurcate; and here and there circular orifices exist, leading to smaller air-sacs. If we trace the air. sacs from their fundus, we may say that, passing from the periphery of the lobulette, and diminishing somewhut in size, they all terminate in the dilated extremity of the bronchial

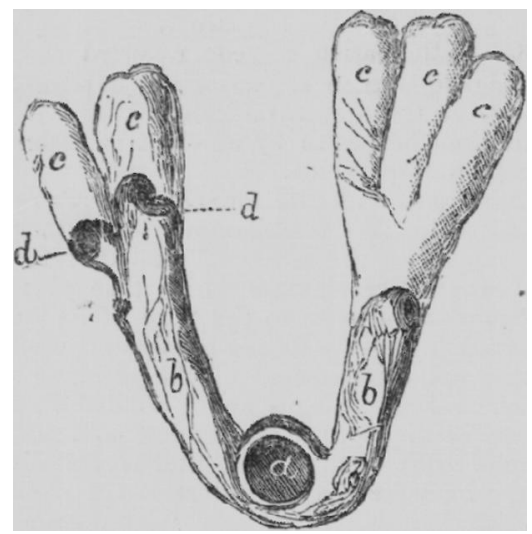

Fig. 2.- Healthy II uman Lung. (From an infant under one year of age.) Two terminal bronchial tubes with two groups of gir-sacs, or lobulettes, divided horizuntally. $a a$, large bronchial tube $z$, termiual bronchial tube; $c c c$, air-sacs; $d d$, openings leading to air-sacs beneath those exposed.

tube; as they thus proceed, they often join two or three together, and these terminate in a single mouth. The tube which results from the union of two or more sacs, is smaller in capa. city than the sacs taken together, but greater than either of them individually. The dilated extremity of the bronchial tube, above alluded to, constitutes the point de réunion of all the air-sacs, and may be considered as the common centre of the lobulette. The air-sacs of the adult human lung vary in diameter from 1.45th to 1-85th of an inch. (See Figs. 1, 2, 3.)

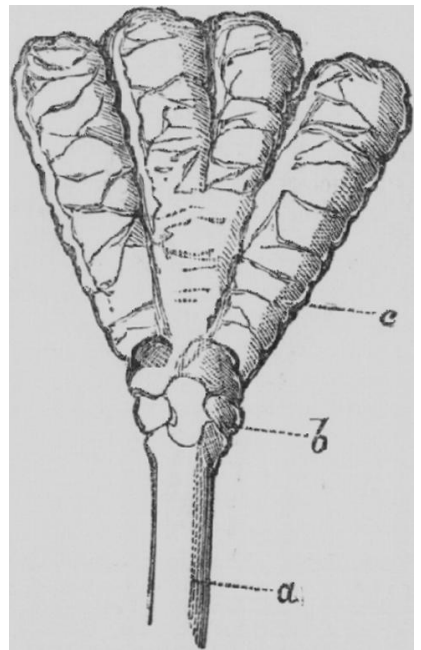

Fig. 3.-Theoretical view of the ultimate pulmonary tissue-viz., tor minul bronchial tube, its dilated extremity, and its groun of ai sacs, or lobulette-divided transversely. a, terminal bronchis tubu; $b$, cavity in which the air-sacs end; $c c$, the ajr-saos (th central one is Been to divide). The markings denote the alveoli of the air-sacs, and of the dilated extremity of the bronchial tube.

The walls of which the air-sacs are composed, are exceed. ingly thin and much sacculated; i.e., they have in them a number of small, shallow, cup-lite depreacions, separtiod tron each other by portions of membrane, which are more or lew raised, and project into the interior of the sac. The bottom of the air-sec presents the sume appenranoe the lateral walls and the cup-like depressions, or alveoli, are there very numerons. (See Fig. 4.) The number of these alveoli varies very much; I have counted as many as ten at the fundus of an air. sac in a cat's lung; in the human lung $I$ have counted fire and six, but the number is not usually quite 80 great. I have found the entire number in each air-sac varying from eight to twenty.

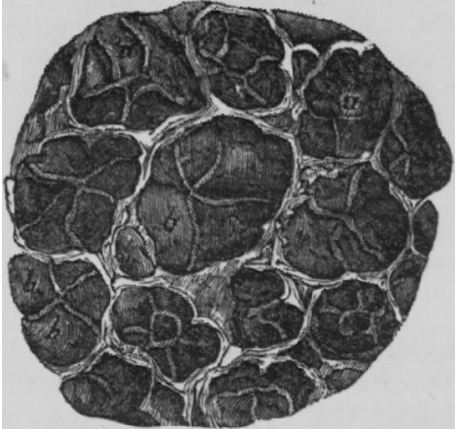

Fig. 4 represents a very thiu slice of a cat's lung (injected, inflated, and dricd, from the surface of the lung. The eye is looking upon the dricd), from the cut surface. The depressions, $a$ a, are the borloms of the air sacs, resting on the plcurn. Tho inght coloured lines that sur. round them are their whils, and tho gmall depressions seen within the walls, $b b$, marked off by less distinct lines, are the alveoli. The s)coimen from which this drawing was made, was a very good one, and the drawing may be consldered as fairly representing the appearance presented.

The air-sacs externally, by their fundus, rest on the pleura, but within the substance of the lung they in part rest on, and are supported by, the bronchial tubes and blood-ressels.

The air-sacs are separated from each other by thin walls, the membrane composing which, in a lung inflated and dried, is rery transparent. The projection of this membrane in the shape of thin processes, having a sharp margin, constitutes the septa between the alveoli; and wherever an opening exists leading into a smaller sac, this membrane projects in a similar way, and forms a circular oritice, which is much smaller than the cavity to which it leads; the sac, in fact, dilates abruptly on the distal side of the opening. It is in the membrane com. posing these walls, and in the septa of the alveoli, that the capillaries of the pulmonary artery are spread out.

Each lobulette is separated from those by which it is sur. rounded by walls which appear to resemble in every way the walls of the air-sacs; and in an adult inflated and dried lung, careful observation is necessary to make out the partitions. That perfect septa do exist, is proved by laying open, in a recent lung, a bronchial tube to its ultimate division, when by placing a fine blowpipe in it, and blowing down it, a single lobulette is alone inflated.

As I have before mentioned, $a$ number of the lobulettes con stitutes a lobule. These lobules are of various sizes, their boundaries on the surface of the lung are distinctly seen; they are each surrounded by a membranous wall, which is dense and strong, allowing of no communication between the blood. $\frac{T}{0}$ vessels of udjoining lobules. The lobules are connected toge. ther by a small quantity of areolar tissue, in which the branches of the pulmonary veins take their course.

Structure of the Air-Sacs and Alveoli.

The walls of the air-sacs and alveoli are formed of yellow elastic fibrous tissue, a basement membrane, and an epithelium. The elastic tissue is arranged in bundles, and singly. $\mathbb{D}$ It is found surrounding the mouths of the air-sacs, running through their walls in various directions, and encircling the alveoli. The fibres traversing the walls are placed at some distance from each other, so that spaces are left between them $\mathbb{D}$ where the blood.vessels are uncovered, except by the basement $\mathbb{R}$ membrane and epithelium. At the circumference of the alveoli and at the margins of the sacs, the fibres are often gathered into bundles of considerable size.

It is to this tissue that the elasticity of the air.sacs is due; and the changes which take place in it, in the disease under consideration, constitute one of the most important features of the affection.

The basement membrane is thin, homogeneous, and transparent. It is a prolongation of that lining the bronchial tubes; but it becomes finer and more delicate as it passes from the 
Intter reacale into the air.neces: it is corered by an opitheliom, contisting of amall fiattaned nucleated cells.

Hering premined these observations on the healthy struc. ture of the lung, I pass on to examine the changes it undergoes in the progress of emphysema.

\section{[To be continued.]}

\section{SCROFULOUS DISEASES OF THE EXTERNAL LYMPHATIC GLANDS :}

THEIR NATURE, VARIETY, AND TREATMENT.

By P. C. Price, Esq., Surgeon to the Great Northern Hospital; the Metropolitan Infirmary for Scrofulous Children at Margate; etc.

III.-Tuberculous Disease of the External Lyaphatic GuANDS.

[Continued from p. 818.]

General Treatment. From the earliest times, tuberculous conditions of the lymphatic glands-the true scrofulous glands of both ancient and modern writers - have obtained every kind of treatment which art could suggest. It is needless to recapitulate the various specifics used by the fathers of medicine, and vencrated through a long series of years; and, although the majority have been dismissed from our modern Pharmacopocia, still one is almost inclined to believe that, from persistent use and recommendation, rare virtues were really found in them. 'There is, perhaps, no subject in medicine which calls forth our ridicule so much as the comprehen. sive treatment of scrofulous affections by the older physicians and surgeons of all civilised nations. How vainly do we en. deavour to suppress a smile when reading the long list of specifics which many an ancient writer describes with most un. wavering faith; and how that smile is turned into laughter when, in still later times, we find that our orn countrymen were not hehindhand in awarding (as the courtly John of Gaddesden, of Rosa Anglica fame, has recorded) to the excrement of doves and the blood of weasels an excellent virtue over scrofnlons sores, notwithstanding their inferiority to the efficacy of the rojal touch! Through centuries, when learning and science in other tranches were fast improving, the same superstitious ignorance directed the skill and practice of many (for that time) excellent physicians; and it is in vain we look for any really definite and sensible employment of medicinal means in the treatment of scrofulous affections, till Wiseman, deploring the want of accurate knowledge on the subject, wrote his celebrated treatise on The Struma or King's Evil, in the reign of our Charles II. From this period, physicians and surgeons seemed to vie with one another in rendering the treatment of the disease as scientific and simple as possible; so that at the present time it may be justly said that, in tho hands of educated men there is no affection of common occurrence which meets with more skilful management.

The general treatment required in the management of cases of tuberculous disease of the external lymphatic glands may be thus considered : firstly, in giving due attention to what may be called the natural requirements of bodily health, sucb as good and nutritious nourishment, pure and fresh air, combined with light, and the enjoyment of healthy exercise; secondly, in the administration of certain medicines.

Tuberculous disease of the external absorbent glands has already been shown to occur in individuals in whom the constitutional powers are low, or affected by certain peculiarities which render them more than ordinarily susceptible to various kinds of diseased action; and hence, proper attention to the natural requirements of health, and the administration of certain efficacious medicines, often tend very greatly to improve and renovate impaired conditions of constitution.

My own observations lead me to believe that the occurrence of glandular tuberculosis is most intimately associated with depraved states of the general powers; and I am convinced that, in a very large proportion of cases, the earliest manifestation can be traced to a period in the life of the patient when an insufficient diet and imperfect sanitary comforts formed the meagre supports of a frame which, perchance, had already sown within it the seeds of hereditary tendency to mischief. Dr. Tyler Smith, in his work on Scrofula, has well insisted on this point; while the practical researches of Lugol, Baudelocque, Guersant, Hufeland, Phillips, Lebert, etc., have likewise corroborated what, on very slight consideration, appears so apparent.
At the Childron': Eoopital at Margete, many of the little patients, when admitted, are the subjects of both incipient and advanced tuberculous disease of the lymphatio glends; and oftentimes they are in such a low and imporerished state thet it is astonishing not to find still worse forms of scrofule than are generally seen. These cbildren are rapidly improved, and rendered far less susceptible of continued and fresh attacks of disease, by a liberal and sustaining diet; and while, doubtlesa, improvement is in some way due to the medicinal means that are employed, still $I$ am persuaded that the greater amount of good is effected by a proper allowance of those resources which Nature has provided for revivifying the flagging powers of a worn and distressed constitution.

In addition, it is all important that, besides good and nutritious diet, pure, fresh, and invigorating air, with well lighted and ventilated apartments, should be afforded to scrofulous patients, and especially to those who are the subjects of direct tuberculous conditions of the glands and other organs. I can. not, while endeavouring to impress most strongly the necessity of due attention to the use of natural and sanitary measures, as taught me by a large experience in the treatment of all kinds of scrofulous maladies, avoid quoting from Dr. Smith's valu. able work the following:- "In the place referred to (a union workhouse in Kent), the parish surgeon reported that, on the 20th April, 18t1, there viere then in the house seventy-eight boys and ninety-four girls; and that all the seventy-eiglit boys had enlargement of the neck, and forty-two had likewise goitre; that of the girls and infants, ninety-one had enlarged glands at the back of the neck, and forty-three also goitre.... The diet in these cases had been bread and cheesu for dinner four times a week; suet pudding and vegetables two days, on the Poor-law scale; and meat only one day of the week for dinner, and then the nsual stinted workhouse quantity. Besides this scanty and innutritious food, which may, for yrowing children, be truly called a scrofulous diet, the dormitories were ill ventilated and excessively crowded." (P. 39.)

In contrast with this scale of diet, I submit that in use by $\mathbf{M r}$. Weckley, the excellent and kind hearted manager of the Children's Infirmary at Margate, for those patients who are convalescent, and able to enjoy the ont-door advantages of this well conducted establishment; while every necessary is granted to those who require more important medical and surgical treatment.

Diet List of the Metropolitan Infirmary for Scrofulous Children at Margate.

FROM FIVE TO TEN YEARS OF ACE.

\begin{tabular}{|c|c|c|}
\hline Breakfast. & Dimuer. & Supper. \\
\hline $\begin{array}{l}\text { Four or five oz. } \\
\text { bread and } \\
\text { butter, and } \\
\text { 3-pint nillk } \\
\text { in water. }\end{array}$ & $\begin{array}{l}\text { Three or four oz. roast or } \\
\text { boiled meat, with z-lb. } \\
\text { potatoes, or potatoes and } \\
\text { brcad, or other vegetables, } \\
\text { J-pint London porter, on } \\
\text { Sunday, Monday, Tuesday, } \\
\text { Thursday, and Friday. } \\
\text { Eight or twelve o\%. of either } \\
\text { rice or currant pudding, on } \\
\text { Wednesday and Saturday. } \\
\text { Soup occasionally, in lieu } \\
\text { of pudding. }\end{array}$ & $\begin{array}{l}\text { Four or five oz. } \\
\text { bread and but- } \\
\text { ter, and } \downarrow-\text { pint } \\
\text { milk in water. }\end{array}$ \\
\hline
\end{tabular}

\begin{tabular}{|c|c|c|}
\hline Breakfust. & Dinuer. & Supper. \\
\hline $\begin{array}{c}\text { Six or seven oz. } \\
\text { bread and } \\
\text { butter, and } \\
\text { s-pint of tea. }\end{array}$ & $\begin{array}{l}\text { Five or six o7. roast or } \\
\text { boiled meat, with } 1 \mathrm{lb} \text {. po. } \\
\text { tatoes, or other vegetables, } \\
\text { or } \frac{1}{2} \cdot \mathrm{lb} \text {. potatoes, and } 3 \mathrm{oz} \text {. } \\
\text { bread, t.pint London por- } \\
\text { ter, on Sunday, Monday, } \\
\text { Tuesday, 'Thursday, and } \\
\text { Friday. } \\
\text { Sixteen oz. of either plum } \\
\text { or currant pudding, on } \\
\text { Wednesday and Saturday. } \\
\text { Soup occasionally, in lieu } \\
\text { of pudding. }\end{array}$ & $\begin{array}{l}\text { Six or seven oz. } \\
\text { bread and but- } \\
\text { ter, and } s \cdot \text { pint } \\
\text { of tea. }\end{array}$ \\
\hline
\end{tabular}

* The quantity of porter or stont, which is the very best, is controlled by the order of the medical officers; as, indeed, are all the articles of food, which are most liberally allowed, according to the requirements of indiridual cases. 